\title{
Metabolic markers of developmental competence for in vitro-matured mouse oocytes
}

\author{
Kimberly A Preis ${ }^{1,2}$, George Seidel Jr${ }^{2}$ and David K Gardner ${ }^{1}$ \\ ${ }^{1}$ Colorado Center for Reproductive Medicine, 799 East Hampden Avenue, Englewood, CO 80113, USA \\ ${ }^{2}$ Department of Biomedical Sciences, Colorado State University, Fort Collins, CO 80523-1683, USA
}

Correspondence should be addressed to D K Gardner; Email: dgardner@colocrm.com

\begin{abstract}
In vitro maturation of oocytes has enormous potential in assisted reproductive technology, but its use has been limited due to insufficient knowledge of oocyte physiology during this dynamic period and lack of an adequate maturation system. The aim of this study was to characterize the metabolic profiles of three groups of oocytes throughout maturation: cumulus-oocyte complexes (COCs), denuded oocytes, and denuded oocytes co-cultured with cumulus cells. Mouse oocytes were collected from 28-day-old unstimulated females and matured in a defined medium. Oocytes were matured individually and transferred into fresh $0.5 \mu \mathrm{l}$ drops of medium at $4 \mathrm{~h}$ intervals until $16 \mathrm{~h}$. Ultramicrofluorimetry was used to quantitate carbohydrate consumption from and metabolite release into the medium. Glucose consumption and lactate production of COCs increased $(P<0.001)$ over the maturation interval $(0-16 h)$. Glucose consumption by COCs that subsequently fertilized was higher between $8-12 \mathrm{~h}$ of maturation than by COCs that did not fertilize (38 versus $29 \mathrm{pmol} / \mathrm{COC}$ per $\mathrm{h}$, respectively; $P<0.01)$. Lactate production by COCs that subsequently fertilized was higher between 8-16 $\mathrm{h}$ of maturation, than by oocytes that did not fertilize $(8-12 \mathrm{~h}, 66$ versus $46 \mathrm{pmol} / \mathrm{COC}$ per $\mathrm{h}, P<0.01 ; 12-16 \mathrm{~h}, 56$ versus $40 \mathrm{pmol} / \mathrm{COC}$ per $\mathrm{h}$, respectively; $P<0.05)$. These data indicate that the final hours of maturation may hold a unique marker of oocyte competence, as during this time fertilizable COCs take up more glucose and produce more lactate than those not subsequently fertilized.
\end{abstract}

Reproduction (2005) 130 475-483

\section{Introduction}

Meiotically competent oocytes will mature spontaneously once released from the follicle if matured under appropriate conditions (Pincus \& Enzmann 1935). Maturation rates vary between, as well as within, species and depend on medium composition and whether immature oocytes were collected from females primed with follicle-stimulating hormone (FSH) prior to oocyte collection or unprimed females; that is, those not receiving $\mathrm{FSH}$. Reported ranges in the mouse are $67-73 \%$ metaphase II (MII), unprimed (De La Fuente et al. 1999), and 89\% MII, primed (Fagbohun \& Downs 1992). Maturation rates are routinely determined by the expulsion of a polar body, representing nuclear maturation. However, developmental competence of oocytes is acquired through completion of both nuclear and cytoplasmic maturation. Only a small portion of in vitro-matured oocytes go on to develop into blastocysts, whereas oocytes matured in vivo have much higher embryo development rates (Van de Leemput et al. 1999, Blondin et al. 2002). Low blastocyst formation by in vitromatured oocytes indicates that current oocyte maturation systems do not adequately support either nuclear and/or cytoplasmic maturation.

Understanding energy substrate metabolism of the oocyte throughout in vitro-maturation may aid in optimizing maturation conditions. Energy requirements of the cumulus-oocyte complex (COC) are unique, as the cumulus cells and oocyte have different metabolic needs. Denuded mouse oocytes require pyruvate or oxaloacetate in the medium in order to mature, whereas COCs develop in medium containing lactate, phosphoenolpyruvate, or glucose (Biggers et al. 1967). Cumulus cells metabolize alternative substrates, such as glucose, which ultimately produce substrates that the oocyte requires for maturation.

Metabolism has been assessed in the mouse oocyte by several groups; however, experimental designs allowed for only a single time-point measurement of individual oocytes (Roberts et al. 2004) or multiple measurements throughout maturation using groups of oocytes, thus making correlation with meiotic status and subsequent embryo development difficult (Downs et al. 2002). Additionally, oocytes used in most studies were collected from mice 
primed with exogenous gonadotropins, which may alter the metabolic profile of the recovered oocytes (Downs et al. 1996, Fagbohun \& Downs 1992). Oocytes recovered from mice primed with equine chorionic gonadotropin (eCG) have higher maturation, two-cell and blastocyst rates (De La Fuente et al. 1999). However, ovarian stimulation in mice has been associated with delayed embryonic development, fetal growth retardation, and increased fetal loss (Edwards et al. 2004, Ertzeid \& Storeng 2001, Van der Auwera \& D'Hooghe 2001). Supplementation of maturation medium with $\mathrm{FSH}$ has varying effects on oocyte developmental competence based on age of donor mice and in vivo priming with gonadotropins. After in vitro maturation in the presence of $\mathrm{FSH}$, oocytes collected from primed 22-24-day-old mice displayed increased developmental competence (Downs et al. 1986). However, in older mice (26 days) FSH supplementation in the maturation medium produced improved developmental competence only in oocytes collected from unprimed mice, with no effect seen in oocytes collected from primed mice (Eppig et al. 1992). Additionally, when gonadotropins are supplemented in the maturation medium of oocytes recovered from both primed and unprimed mice, the metabolic profiles differ between groups. When immature oocytes were collected from unprimed mice and subsequently matured with or without $\mathrm{FSH}$, the FSH groups had higher glucose uptake and higher production of both lactate and pyruvate (Roberts et al. 2004). In addition to altering carbohydrate uptake and production, maturation in the presence of FSH changes substrate metabolism. COCs principally metabolize glucose via glycolysis, and the addition of FSH in the medium increases glycolysis 2.7-fold (Downs and Utecht 1999). Futhermore, supplementation of $\mathrm{FSH}$ into maturation medium induced aneuploidy in in vitro-matured mouse oocytes (Roberts et al. 2005).

In addition to assisting medium optimization, metabolic profiles may also serve as a potential marker of oocyte viability. Oocyte morphology is often used as a predictor of development; however, this is not a very accurate method of selection. Nuclear and cytoplasmic maturation are often asynchronous. Cytoplasmic maturation is required for activation of the oocyte at fertilization and subsequent embryo development. The oocyte's cytoplasm provides the appropriate metabolic machinery for production of energy for cellular functions during maturation, fertilization, and embryo development. Metabolic profiles of mouse embryos have been established as valuable indicators of embryo viability (Gardner \& Leese 1987, Lane \& Gardner 1996). The use of noninvasive metabolic assays would quantify oocyte characteristics and potentially result in a method of predicting developmentally competent oocytes.

The metabolic profiles of individual mouse oocytes throughout maturation have not been studied in the unstimulated mouse. The first objective of this study was to characterize the metabolic profile of the individual oocyte throughout maturation. Three categories of oocytes were included: COCs, denuded oocytes, and denuded oocytes matured in the presence of cumulus cells. The second objective was to compare metabolic profiles of COCs that matured and fertilized versus COCs that exhibited nuclear maturation, but failed to fertilize.

\section{Materials and Methods}

\section{Experiment 1: Characterization of oocyte metabolism throughout in vitro maturation}

Oocyte collection, in vitro maturation, fertilization, and culture

Oocytes were collected from unstimulated 28-day-old $(\mathrm{C} 57 \mathrm{BL} / 6 \times \mathrm{CBA}) \mathrm{F}_{1}$ female mice. Antral follicles were removed from ovaries with sterile 30-gauge needles and COCs were released into the collection medium (G-MOPS plus 5\% bovine calf serum; Lane \& Gardner 2004). Oocytes were rinsed three or four times in a defined maturation medium (Modified G2 with $0 \mathrm{mM}$ lactate, $0.23 \mathrm{mM}$ pyruvate, $0.5 \mathrm{mM}$ glucose, $2.5 \mathrm{mg} / \mathrm{ml}$ human recombinant serum albumin (Delta Biotechnology, Nottingham, UK), $0.5 \mathrm{mM}$ citrate, $0.5 \mathrm{mM}$ cysteamine, $100 \mathrm{ng} / \mathrm{ml}$ epidermal growth factor (EGF), ITS (insulin $(0.5 \mu \mathrm{g} / \mathrm{ml}$ ), transferrin $(0.275 \mu \mathrm{g} / \mathrm{ml})$ and selenium $(0.25 \mathrm{ng} / \mathrm{ml}))$ and $2 \mathrm{mg} / \mathrm{ml}$ fetuin; Gardner et al. 2001), prior to being placed into final culture drops. Unless otherwise noted, all chemicals and hormones were purchased from Sigma (St Louis, MO, USA) and prescreened for embryo toxicity using a sequential mouse pronucleate embryo assay (Gardner et al. 2005). Oocyte maturation, fertilization, and embryo culture were performed in $60 \mathrm{~mm}$ (3652) Falcon dishes (Becton Dickinson, Franklin Lakes, NJ, USA). Oocytes were matured individually at $37^{\circ} \mathrm{C}$ in $6 \% \mathrm{CO}_{2} / 5 \% \mathrm{O}_{2} / 89 \% \mathrm{~N}_{2}$ in $0.5 \mu \mathrm{l}$ drops of medium under paraffin oil (Ovoil; Vitrolife, Gothenburg, Sweden). Oocytes were transferred into a fresh $0.5 \mu \mathrm{l}$ drop of medium every $4 \mathrm{~h}$, until $16 \mathrm{~h}$. After oocytes were removed, the medium was frozen and stored at $-80^{\circ} \mathrm{C}$ for subsequent analysis. Oocytes were transferred into individual drops of fertilization medium at $17 \mathrm{~h}$ post retrieval. For fertilization, all oocytes were denuded, and no cumulus cells were replaced into the medium. Sperm was collected from the epididymis and vas deferens of 3-6-month-old $F_{1}(\mathrm{C} 57 \mathrm{BL} / 6 \times \mathrm{CBA})$ male mice and allowed to capacitate in fertilization medium for $1 \mathrm{~h}$ prior to insemination. Gametes were co-incubated for $8 \mathrm{~h}$, after which presumptive zygotes were transferred individually into $5 \mu \mathrm{l}$ drops of G1 culture medium (Gardner \& Lane 2004). Embryos were transferred into fresh G1 medium after $24 \mathrm{~h}$ and into G2 medium $48 \mathrm{~h}$ post-fertilization. Embryos were cultured individually until $96 \mathrm{~h}$ at which time blastocyst rates were recorded. Oocyte maturation rates were determined by the presence of a polar body at the end of the $17 \mathrm{~h}$ maturation period and again at the end of the fertilization period. All experiments were approved by the Institutional Animal Care and Use Committee. 


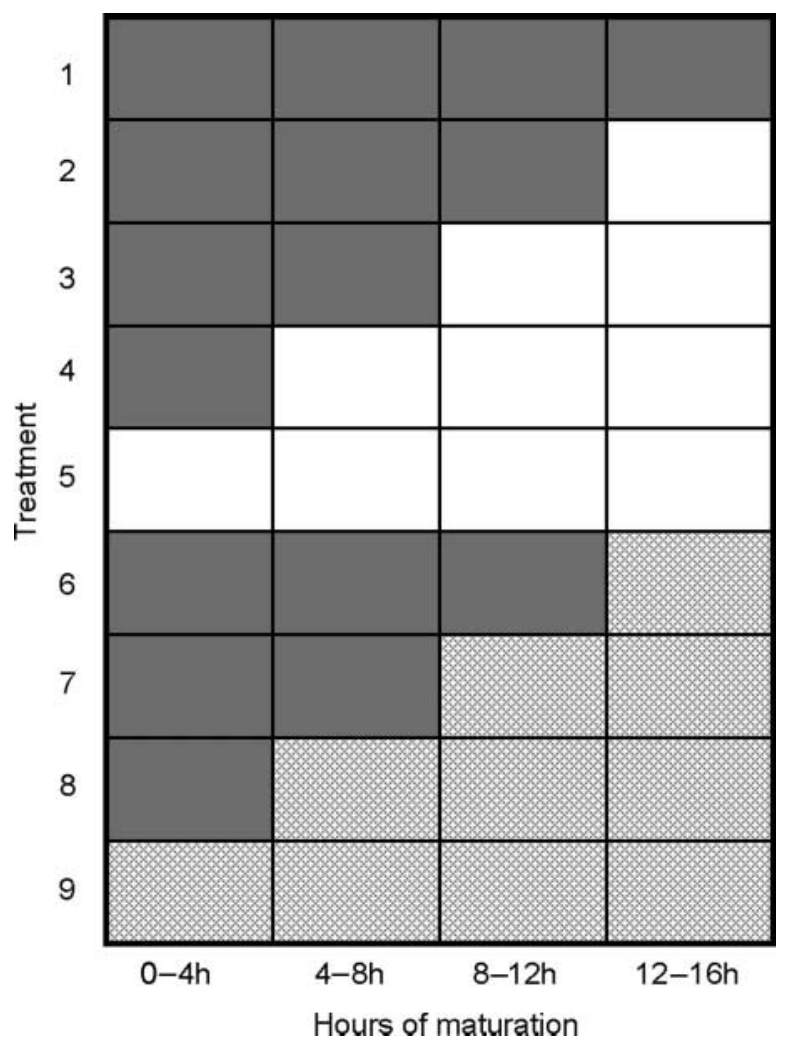

Figure 1 Experimental design for oocytes throughout maturation: COCs (dark-gray squares), denuded oocytes (white squares), and denuded oocytes matured in the presence of cumulus cells (hatched squares).

\section{Assessment of oocyte metabolism}

Oocytes $(n=604)$ were matured in one of nine treatment groups (Fig. 1). A minimum of 50 oocytes were matured in each group. Group 1 was matured with cumulus cells intact throughout maturation $(0-17 \mathrm{~h})$. Cumulus cells were removed from remaining groups at various intervals, and stripped oocytes were matured with or without the presence of cumulus cells. Groups 2, 3, 4, and 5 were denuded at $12,8,4$, and $0 \mathrm{~h}$ respectively, and subsequently matured with no cumulus cells. Groups 6, 7,8 , and 9 were denuded at $12,8,4$, and $0 \mathrm{~h}$ respectively, and their cumulus cells were replaced into the medium for the duration of maturation. Oocytes were denuded in G-MOPS with $1 \mathrm{mg} / \mathrm{ml}$ hyaluronidase. Oocytes and cumulus cells were rinsed three or four times in the defined maturation medium prior to incubation. Control oocytes (COCs, denuded, and denuded plus cumulus) were matured individually in $5 \mu$ drops and remained undisturbed in the incubator until $17 \mathrm{~h}$ of maturation. Fertilization and embryo culture of control oocytes were identical to treatment oocytes.

Metabolism was assessed from a minimum of 14 oocytes per group. Ultramicrofluorimetry was used to quantify the level of carbohydrate production and consumption from maturation medium. Fluorometric assays were based on the generation or consumption of the reduced pyridine nucleotides $\mathrm{NADH}$ or $\mathrm{NADPH}$, which fluoresce when excited with a wavelength of $340 \mathrm{~nm}$ (Leese \& Barton 1984, Gardner \& Leese 1990). Assay cocktails included all necessary enzymes and cofactors needed to carry out the reaction, depending on the carbohydrate being analyzed. All cocktail-to-sample ratios were $10: 1$. For the assay, a $30 \mathrm{nl}$ cocktail drop was placed on a siliconized slide under mineral oil and exposed to $340 \mathrm{~nm}$ to obtain a base reading. A $3 \mathrm{nl}$ sample was then added to the cocktail drop. The reaction was allowed to proceed for $3 \mathrm{~min}$, and a second reading was taken. The difference was determined between the initial reading of the cocktail and subsequent reading of the cocktail plus sample. Concentrations of substrate were calculated though comparison of the change with known quantities calculated from a standard curve $(r>0.99)$ obtained for each carbohydrate on each day of analysis.

\section{Cumulus cell counts}

COCs $(n=56)$ were denuded upon removal from the follicle and divided into four groups. Denuded oocytes were matured with their cumulus cells in $0.5 \mu \mathrm{l}$ drops of medium, with a medium change over every $4 \mathrm{~h}$ as described above. In group 1, cumulus cells were stained and counted following a $4 \mathrm{~h}$ maturation interval. Cumulus cells in groups 2, 3, and 4 were stained following 8, 12, and $16 \mathrm{~h}$ of maturation, respectively. For staining, cumulus cells from individual oocytes were placed into Triton X100 for $45 \mathrm{~s}$ and then placed into a $20 \mu \mathrm{l}$ drop of propidium iodide for a minimum of $5 \mathrm{~min}$. Cells for individual oocytes were counted and cumulus cell numbers from the same group were averaged.

\section{Experiment 2: Assessment of glucose metabolism at 8-12 $\mathrm{h}$ maturation for COCs that fertilized versus COCs that matured and failed to fertilize}

COCs $(n=59)$ were matured in $5 \mu$ l drops of medium until $8 \mathrm{~h}$. At $8 \mathrm{~h}$, oocytes were transferred into $0.5 \mu \mathrm{l}$ drops for $4 \mathrm{~h}$. Following the $4 \mathrm{~h}$ incubation, oocytes were transferred back into the original $5 \mu \mathrm{l}$ drops of maturation medium until $17 \mathrm{~h}$. Oocytes were then fertilized, and presumptive zygotes and embryos were cultured for $96 \mathrm{~h}$. Medium drops from the $4 \mathrm{~h}$ incubation were frozen and stored for glucose analysis.

\section{Experiment 3: Assessment of lactate production at 8-16 h maturation for COCs that fertilized versus COCs that matured and failed to fertilize}

COCs were matured in $5 \mu \mathrm{l}$ drops of medium until 8 or $12 \mathrm{~h}$. At $8 \mathrm{~h}(n=30)$ or $12 \mathrm{~h}(n=44)$, oocytes were transferred into $0.5 \mu \mathrm{l}$ drops for $4 \mathrm{~h}$. Following the $4 \mathrm{~h}$ incubation, oocytes were transferred back into the original $5 \mu \mathrm{l}$ drops of maturation medium until $17 \mathrm{~h}$. Oocytes were then fertilized, and presumptive zygotes and embryos 
were cultured for $96 \mathrm{~h}$. Medium drops from the $4 \mathrm{~h}$ incubation were frozen and stored for lactate analysis.

\section{Statistical analysis}

Preplanned comparisons of maturation and fertilization rates between specific treatment groups were compared using Fisher's exact test. Metabolic profiles were analyzed by one-way analysis of variance or by Kruskal-Wallis test, in cases where variances were heterogeneous. Cumulus cell numbers were analyzed by one-way analysis of variance. Comparisons between metabolic profiles of fertilized and unfertilized oocytes (experiments 2 and 3) were done by Student's $t$-test.

\section{Results}

\section{Experiment 1}

Oocytes in treatment 5 had lower maturation rates than oocytes in group $1(P<0.01)$ and lower fertilization rates than oocytes in groups 1,9 , and control denuded oocytes $(P<0.01$; Table 1). Oocytes in group 1 did not differ from the COC control group in maturation; however, fertilization rates were lower in group 1 than its respective control $(P<0.05)$. Group 9 had a higher maturation rate than the respective control $(P<0.05)$; however, the fertilization rates were similar. Oocytes denuded after $4 \mathrm{~h}$ of maturation and matured with cumulus cells (group 8) had higher maturation rates than oocytes denuded at the same time point, but matured alone (group 4; $P<0.01$ ). Fertilization rates between groups 4 and 8 did not differ. Oocytes denuded at $8 \mathrm{~h}$ (groups 3 and 7 ) did not differ in maturation or fertilization rates. Blastocysts developed in all groups, except group 5. Of groups that formed blastocysts, rates of development were similar.

Glucose and lactate profiles of denuded oocytes matured in the presence of cumulus cells followed similar, though suppressed, metabolic patterns compared with COCs. The two groups of oocytes with cumulus cells had higher glucose uptake throughout maturation, compared with denuded oocytes without cumulus cells (Fig. 2a). COCs and denuded oocytes with cumulus cells had similar glucose uptakes until $8 \mathrm{~h}$ of maturation, at which point COCs had higher glucose uptake for the duration of maturation $(P<0.01)$. A similar pattern was seen in lactate production (Fig. 2b). COCs and denuded oocytes with cumulus cells had higher lactate production than the denuded group. For the first $8 \mathrm{~h}$ of maturation, COCs and denuded oocytes with cumulus cells had similar lactate production. However, after $8 \mathrm{~h}, \mathrm{COCs}$ had higher lactate production $(P<0.01)$. Pyruvate uptake was similar for all three groups over the course of maturation (Fig. 2c). Numbers of cumulus cells replaced back into the maturation medium decreased significantly with each medium change $(P<0.01)$, except for the final change at $12 \mathrm{~h}$ $(0-4 \mathrm{~h}, 1200 \pm 57$ cells; $4-8 \mathrm{~h}, 745 \pm 59$ cells; $8-12 \mathrm{~h}$, $487 \pm 57$ cells; $12-16$ h, $273 \pm 44$ cells).

Glucose uptake of COCs increased throughout maturation $(27 \mathrm{pmol} / \mathrm{COC}$ per $\mathrm{h}$ at $0-4 \mathrm{~h}$ versus $49 \mathrm{pmol} / \mathrm{COC}$ per h at $12-16 \mathrm{~h} ; P<0.01$; Fig. 3). Glucose consumption between $0-4$ and $4-8 \mathrm{~h}$ did not differ significantly (27 versus $30 \mathrm{pmol} / \mathrm{COC}$ per h); however, by $8-12 \mathrm{~h}$ of maturation, glucose uptake increased $(39 \mathrm{pmol} / \mathrm{COC}$ per h; $P<0.05)$. Lactate production of COCs also increased over the maturation interval $(38 \mathrm{pmol} / \mathrm{COC}$ per $\mathrm{h}$ at $0-4 \mathrm{~h}$ versus $62 \mathrm{pmol} / \mathrm{COC}$ per $\mathrm{h}$ at $12-16 \mathrm{~h}$; $P<0.01$; Fig. 3). Like glucose, lactate production began to increase between $8-12 \mathrm{~h}$ ( $44 \mathrm{pmol} / \mathrm{COC}$ per $\mathrm{h}$ at $4-8 \mathrm{~h}$ and $60 \mathrm{pmol} / \mathrm{COC}$ per $\mathrm{h}$ at $8-12 \mathrm{~h} ; P<0.01)$. For the COCs, pyruvate consumption did not change throughout maturation $(13 \mathrm{pmol} / \mathrm{COC}$ per $\mathrm{h}$ at $0-4 \mathrm{~h}$ versus $16 \mathrm{pmol} / \mathrm{COC}$ per $h$ at $12-16 \mathrm{~h})$.

The metabolic profiles of oocytes that fertilized and oocytes that matured but failed to fertilize differed over the course of maturation. Fertilized oocytes had significantly higher glucose uptake from $8-16 \mathrm{~h}$ versus the uptake at $0-8 \mathrm{~h}(P<0.05)$. For oocytes that failed to fertilize, glucose uptake was similar throughout maturation (Fig. 4). For lactate, oocytes that failed to fertilize also had no significant changes throughout maturation; however, oocytes that

Table 1 Maturation, fertilization, and development rates per oocyte.

\begin{tabular}{|c|c|c|c|c|c|c|c|}
\hline Treatment & Total no. of oocytes & No. of MII & MII (\%) & No. fertilized & $\%$ Fertilized/oocyte & No. of blastocysts & \%Blastocysts/oocyte \\
\hline 1 & 50 & 48 & $96^{\mathrm{a}}$ & 28 & $56^{\mathrm{d}, \mathrm{g}}$ & 6 & $12^{\mathrm{h}}$ \\
\hline 2 & 50 & 38 & 76 & 32 & 64 & 12 & 24 \\
\hline 3 & 50 & 47 & 94 & 41 & 82 & 12 & 24 \\
\hline 4 & 50 & 31 & $62^{b}$ & 30 & 60 & 7 & 14 \\
\hline 5 & 53 & 39 & $74^{\mathrm{a}}$ & 12 & $23^{d, e, f}$ & 0 & $0^{h, i}$ \\
\hline 6 & 50 & 48 & 96 & 38 & 76 & 18 & 36 \\
\hline 7 & 50 & 46 & 92 & 34 & 68 & 12 & 24 \\
\hline 8 & 50 & 47 & $94^{b}$ & 30 & 60 & 7 & 14 \\
\hline 9 & 50 & 42 & $84^{c}$ & 32 & $64^{\mathrm{e}}$ & 7 & $14^{\mathrm{i}}$ \\
\hline Control COC & 51 & 42 & 82 & 40 & $78^{\mathrm{g}}$ & 12 & 24 \\
\hline Control DO & 50 & 33 & 66 & 24 & $48^{f}$ & 2 & 4 \\
\hline Control DO + & 50 & 31 & $62^{c}$ & 26 & 52 & 2 & 4 \\
\hline
\end{tabular}

Like pairs within a column are significantly different: ${ }^{\mathrm{c}, \mathrm{g}} P<0.05$; $^{\mathrm{a}, \mathrm{b}, \mathrm{d}, \mathrm{e}, \mathrm{f}, \mathrm{h}, \mathrm{i}} P<0.01$

$\mathrm{DO}$, denuded oocytes; DO+, denuded oocytes matured with cumulus cells 

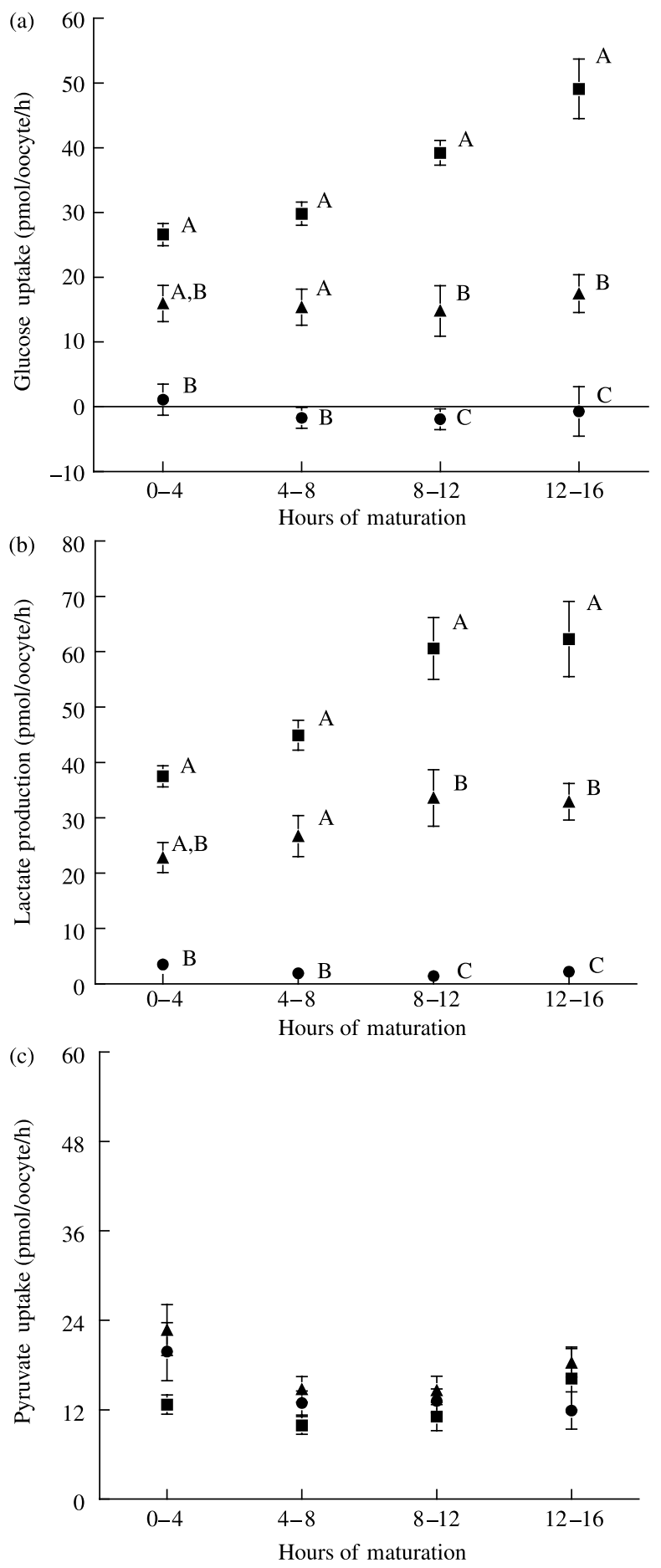

Figure 2 Carbohydrate profiles (means \pm S.E.M.) throughout maturation of COCs $(\mathbf{\square})$, denuded oocytes $(\bullet)$, and denuded oocytes matured in the presence of cumulus cells $(\mathbf{\Lambda})$. Different letters represent differences between groups at individual time points. (a) For glucose uptake, denuded oocytes differed from COCs $(P<0.001)$ at all time points of maturation. Denuded oocytes matured in the presence of cumulus cells differed from COCs at $8-12 \mathrm{~h}$ and $12-16 \mathrm{~h}$ maturation $(P<0.001)$. (b) Denuded oocytes produced significantly less lactate throughout maturation $(P<0.001)$ than COCs. Denuded oocytes matured in the presence of cumulus cells produced less lactate at $8-12 \mathrm{~h}$ and $12-16 \mathrm{~h}$ maturation than COCs $(P<0.05)$. (c) Pyruvate profiles did not differ between groups at any time point.

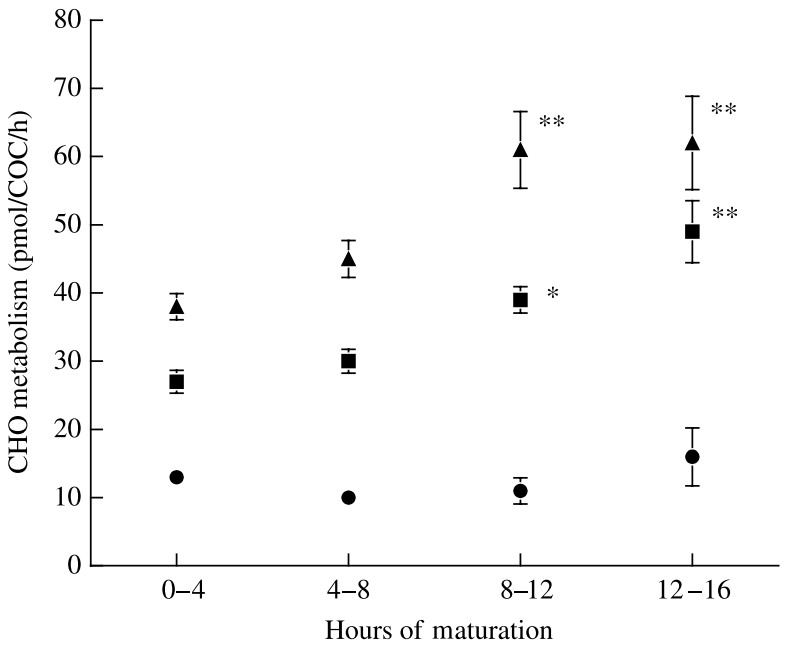

Figure 3 Carbohydrate $(\mathrm{CHO})$ metabolism of COCs throughout maturation. Glucose uptake $(\mathbf{\square})(P<0.05)$ and lactate production $(\mathbf{\Delta})$ were higher at $8-12 \mathrm{~h}(P<0.01)$ and $12-16 \mathrm{~h}(P<0.01)$ than at $0-8$ h. Pyruvate concentration $(\bullet)$ in medium remained similar throughout maturation. Significant differences in relation to individual carbohydrate metabolism over time are indicated by $*(P<0.05)$ and $* *(P<0.01)$.

fertilized had higher lactate production from $8-16 \mathrm{~h}$ compared with $0-4 \mathrm{~h}$ of maturation $(P<0.01$; Fig. 5). Glucose uptake by COCs that subsequently fertilized was higher between 8 and $12 \mathrm{~h}$, than that by oocytes that did not fertilize (38 versus $29 \mathrm{pmol} / \mathrm{COC}$ per $\mathrm{h} ; P<0.01$ ). Although lactate profiles had a tendency to differ between 8 and $16 \mathrm{~h}$, pyruvate profiles were not different between oocytes that subsequently fertilized or did not.

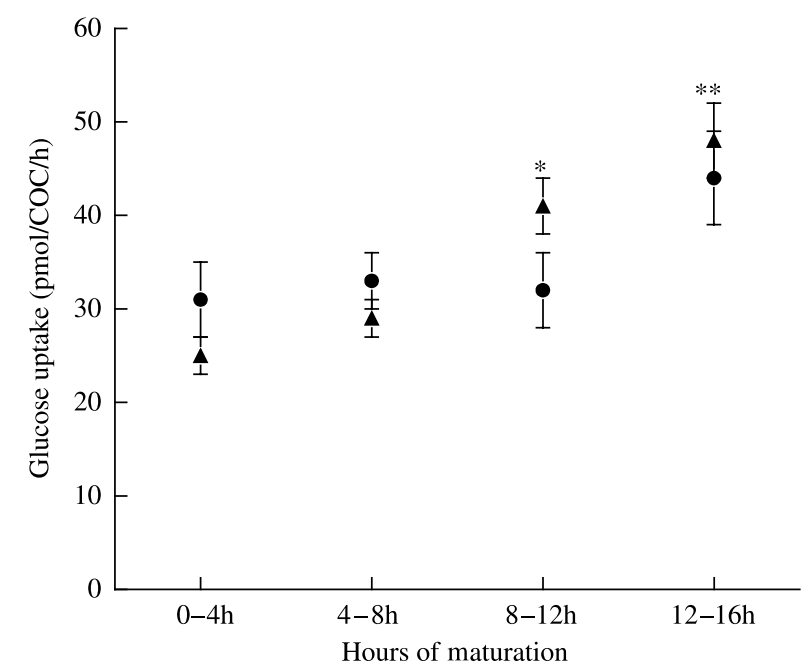

Figure 4 Glucose uptake (means \pm S.E.M.) by COCs that fertilized $(\boldsymbol{\Lambda})$ versus COCs that failed to fertilize $(\bullet)$. Glucose uptake increased over the maturation period for COCs that fertilized $(0-8$ versus $8-12 \mathrm{~h}, * P<0.05 ; 0-8$ versus $12-16 \mathrm{~h}, * * P<0.01)$. COCs that failed to fertilize had similar glucose uptake throughout maturation. 


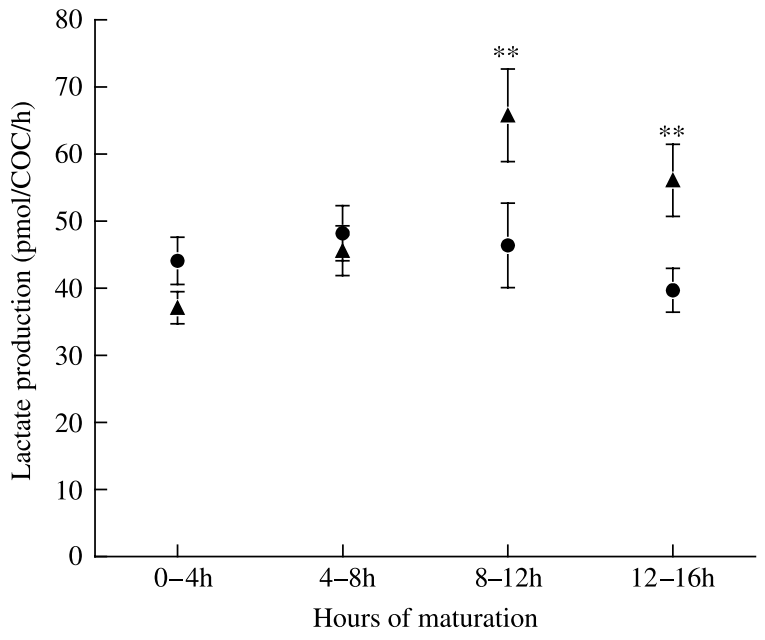

Figure 5 Lactate production (means \pm S.E.M.) by COCs that fertilized $(\boldsymbol{\Lambda})$ versus COCs that failed to fertilize $(\bullet)$. COCs that fertilized had increased lactate production over the final half of maturation $(0-4$ versus $8-16 \mathrm{~h}, * * P<0.01)$. COCs that failed to fertilize did not have an increase in lactate production throughout maturation.

\section{Experiment 2}

Experiments 2 and 3 were carried out to confirm the results of experiment 1 , but only one 4 -h metabolic incubation was performed during the maturation process. COCs undergoing metabolic analysis had 82\% (89/109) maturation and a $69 \%(61 / 89)$ fertilization rate compared with $70 \%(21 / 30)$ and $100 \%$ maturation and fertilization rates of control oocytes. Eight blastocysts developed in the treatment group (13\%) compared with 11 in the control group $(37 \%)$. At $8-12 \mathrm{~h}$ of maturation, fertilized oocytes consumed an average of $37 \mathrm{pmol} / \mathrm{COC}$ per $\mathrm{h}$, and unfertilized oocytes consumed 29 pmol/COC per h $(P<0.01$; Table 2), confirming the finding of experiment 1.

\section{Experiment 3}

COCs undergoing metabolic analysis had an 86\% (49/57) maturation rate, identical to controls. Fertilization and blastocyst rates were not different between treatment and control (68 and 24\% compared with 47 and $27 \%$, respectively). Lactate production during $8-16 \mathrm{~h}$ was significantly higher for oocytes that fertilized compared with those that did not fertilize. At $8-12 \mathrm{~h}$ maturation, oocytes that fertilized produced on average 66 compared with $46 \mathrm{pmol} / \mathrm{COC}$ per $\mathrm{h}$ by oocytes that failed to fertilize, and at $12-16 \mathrm{~h}$ oocytes that fertilized produced 56 compared with $40 \mathrm{pmol} / \mathrm{COC}$ per $\mathrm{h}$ by oocytes that did not fertilize $(P<0.05$; Table 2).

\section{Discussion}

In the present study, there were several differences in maturation and fertilization rates among treatments. When oocytes were denuded upon removal from the follicle, maturation and fertilization were enhanced in the presence of cumulus cells and were not different from intact COCs. The results confirm previous work where the frequency of fertilization was lower when mouse oocytes (Schroeder \& Eppig 1984) and bovine oocytes (Zhang et al. 1995, Fatehi et al. 2002) were matured in the absence of cumulus cells. Denuding oocytes later in the maturation process and maturing without cumulus cells may have deleterious effects on maturation rates; however, developmental potential was not impacted. Oocytes in all groups were fertilized without cumulus, indicating that cumulus cells are not required for fertilization.

Blastocyst development was lower in this study compared with other studies for several reasons. First, oocytes and embryos were matured and cultured individually as opposed to groups. Oocytes and embryos in groups may benefit from the sharing of paracrine factors among one another, potentially enhancing developmental competence. Second, the high level of oocyte manipulation throughout the course of in vitro maturation could have resulted in reduced developmental rates. Finally, the literature has reported a wide range of blastocyst development from in vitro-matured mouse oocytes, with higher percentages of blastocysts being produced from protocols including in vivo gonadotropin priming and/or inclusion of FSH in the maturation medium (Eppig et al. 1992, Merriman et al. 1998, Schroeder et al. 1988).

Throughout maturation change-overs took place every $4 \mathrm{~h}$. Numbers of cumulus cells in group 9 decreased over time. Previous estimates of the number of cumulus cells surrounding an individual mouse oocyte averaged 2060 cells (Leese \& Barton 1985). The average number of cells initially placed with each oocyte was 1200. During the maturation process some cells plated to the dish, preventing transfer to the subsequent medium drop. Loss in cumulus cells affected metabolic analysis, perhaps leading to the differences between the COC and the denuded group matured with cumulus cells during the last $8 \mathrm{~h}$ of maturation. Additionally, cumulus cells decrease glucose oxidation once removed from the oocyte (Zuelke \& Brackett

Table 2 Glucose uptake and lactate production by COCs that fertilized compared with COCs that failed to fertilize at $8-12$ and $12-16 \mathrm{~h}$.

\begin{tabular}{|c|c|c|c|c|}
\hline & 8-12 h, Fertilized & 8-12 h, Unfertilized & $12-16 \mathrm{~h}$, Fertilized & 12-16 h, Unfertilized \\
\hline Glucose uptake (pmol/COC per h) & $37 \pm 1.5^{\mathrm{a}}$ & $29 \pm 2.1^{\mathrm{a}}$ & $48 \pm 2.9$ & $44 \pm 2.9$ \\
\hline Lactate production (pmol/COC per h) & $66 \pm 6.9^{b}$ & $46 \pm 6.3^{b}$ & $56 \pm 5.3^{\mathrm{c}}$ & $40 \pm 3.3^{\mathrm{c}}$ \\
\hline
\end{tabular}

Like pairs within rows are significantly different: ${ }^{c} P<0.05 ;{ }^{a, b} P<0.01$. Means \pm S.E.M. are shown. 
1992). Both of these factors would influence the metabolic profile of this group of oocytes and may account for the differences between the COC group.

This study shows that the metabolic profile of developmentally competent oocytes changes throughout maturation. Metabolic activity of COCs increased toward the end of maturation. It is important to acknowledge that the maturation conditions and medium, as well as the source of the oocytes (primed versus unprimed mice), will affect metabolism of the oocyte. Under the present conditions of maturation in a defined system, the beginning hours of maturation are relatively quiescent, and towards $11 \mathrm{~h}$ of maturation the COC increases in metabolic activity. The increased uptake and production of nutrients by the COC during this time may reflect the need to support various processes associated with completion of both nuclear and cytoplasmic maturation. As stated above, a change in the maturation conditions may result in changes in the metabolic profile. For example, FSH-primed mice or oocytes matured in the presence of FSH may show an increase in metabolism at an earlier time point in the maturation process, as oocytes matured in the presence of FSH reach maturation sooner than non-FSH-treated oocytes (Roberts et al. 2004). In future studies, the use of this defined maturation system will allow for changes in medium composition, such as the addition of FSH and/or $\mathrm{LH}$, to be directly correlated to changes in oocyte metabolism and developmental potential.

In the present study, metabolic activity of oocytes during later stages of maturation correlated with developmental competence of in vitro matured COCs. Few groups have examined the relationship between metabolism, oocyte maturation, and developmental competence. In the mouse, COCs progressing through meiosis and denuded oocytes have a greater requirement for pyruvate than prophase $\mathrm{I}$ - or MIl-arrested oocytes (Downs et al. 2002). Higher rates of glycolysis by bovine oocytes denuded at the end of a 24-h maturation period were associated with increased developmental potential (Krisher \& Bavister 1999). Blastocyst development in cats was also associated with higher rates of glycolysis by denuded oocytes; however, no correlation was determined between glycolytic activity or glucose oxidation by cumulus cells and subsequent oocyte development (Spindler et al. 2000). In the present study, COCs that were able to fertilize consumed more glucose and produced more lactate than the oocytes that failed to fertilize. This increase in metabolism may indicate healthier oocytes.

Lactate production increased in fertilized COCs throughout the maturation process, indicating an increase in glycolysis in the later half of maturation. During the first $12 \mathrm{~h}$ of maturation of COCs, approximately three-quarters of glucose is being converted to lactate, whereas during the final $4 \mathrm{~h}$ of maturation less than two-thirds of the glucose is being converted to lactate. However, actual glycolytic rates cannot be calculated from this study, as pyruvate was included in the maturation medium. Pyruvate in the medium could have been converted to lactate, thus artificially increasing the lactate production.

Synthesis of extracellular matrix by cumulus cells in the later stages of maturation leads to mucification and expansion of cumulus cells. It has been shown that the addition of glucosamine to medium reduces the total glucose uptake by bovine COCs during the final stages of maturation (Sutton-McDowall et al. 2004). When glucosamine is not included in the medium, as in the present study, a portion of glucose must be utilized in this pathway to produce the extracellular matrix component hyaluronic acid. The same phenomenon has been demonstrated in the mouse under FSH induction of meiosis (Salustri et al. 1989); however, in the present study no FSH was added to the medium, although EGF was included, which has also been shown to act on cumulus cells to trigger germinal vesicle breakdown (Downs et al. 1988, De La Fuente et al. 1999). Another route of glucose consumption that has been shown to play a large role in oocyte maturation is the pentose phosphate pathway (Downs \& Utecht 1999, Downs et al. 1998). Towards the end of maturation, the increase flux of glucose though the pentose phosphate pathway allows increased production of substrates involved in nuclear maturation (Sutton et al. 2003). COCs that fertilized consumed a larger amount of glucose in the later half of maturation than those that did not fertilize, thus allowing these COCs to generate increased energy not only though glycolysis, but also through alternative biosynthetic pathways that yield products necessary for complete nuclear and cytoplasmic maturation.

In conclusion, developmental and metabolic data generated from this study have implications for both research and clinical settings. First, when COCs are denuded for procedures such as intracytoplasmic sperm injection and are found to be immature, they are sometimes placed back into maturation until they reach MII. The data from this study suggest that developmental competence will be enhanced when cumulus cells are placed in the medium with germinal vesicle (GV) or metaphase I-denuded oocytes. Second, metabolic data differed between COCs that subsequently fertilized and those COCs that matured but failed to fertilize. Not only did the glucose and lactate profiles of developmentally competent COCs change throughout maturation, but glucose uptake and lactate production were higher for oocytes that subsequently fertilized compared with those that failed to fertilize. Therefore, glucose and lactate profiles may provide a non-invasive measurement of oocyte viability. At this point, the overlap between COCs that fertilize and those that fail to fertilize does not allow this assessment to prospectively predict which oocytes will fertilize. However, the use of metabolic assessments would allow for COCs with higher glucose uptake and lactate production to be subsequently grouped together, allowing the healthier oocytes to benefit from shared paracrine factors. The use of metabolic markers, in conjunction with other established markers of oocyte viability, should facilitate improvements in the in vitro 
maturation system, allowing evaluations of in vitro-maturation systems to expand from solely morphological criteria to non-invasive quantitative assessment.

\section{Acknowledgements}

We thank Dr Mark Larman for providing valuable advice and comments on the manuscript and the Colorado Center for Reproductive Medicine for support of this study. The authors declare that there is no conflict of interest that would prejudice the impartiality of this scientific work.

\section{References}

Biggers J, Whittingham D \& Donahue R 1967 The pattern of energy metabolism in the mouse oocyte and zygote. PNAS 58 560-567.

Blondin P, Bousquet D, Twagiramungu H, Barnes F \& Sirard MA 2002 Manipulation of follicular development to produce developmentally competent bovine oocytes. Biology of Reproduction $6638-43$.

De La Fuente R, O’Brien MJ \& Eppig JJ 1999 Epidermal growth factor enhances preimplantation developmental competence of maturing mouse oocytes. Human Reproduction 14 3060-3068.

Downs SM \& Utecht AM 1999 Metabolism of radiolabeled glucose by mouse oocytes and oocyte-cumulus cell complexes. Molecular Reproduction and Development 60 1446-1452.

Downs SM, Schroeder AC \& Eppig JJ 1986 Developmental capacity of mouse oocytes following maintenance of meiotic arrest in vitro. Gamete Research 15 305-316.

Downs SM, Daniel SA \& Eppig JJ 1988 Induction of maturation in cumulus cell-enclosed mouse oocytes by follicle-stimulating hormone and epidermal growth factor: evidence for a positive stimulus of somatic cell origin. Journal of Experimental Zoology 245 86-91.

Downs SM, Humpherson PG, Marin KL \& Leese HJ 1996 Glucose utilization during gonadotropin induced meiotic maturation in cumulus cell enclosed mouse oocytes. Molecular Reproduction and Development 44 121-131.

Downs SM, Humpherson PG \& Leese HJ 1998 Meiotic induction of cumulus cell enclosed mouse oocytes: involvement of the pentose phosphate pathway. Biology of Reproduction 58 1084-1094.

Downs SM, Humpherson PG \& Leese HJ 2002 Pyruvate utilization by mouse oocytes is influenced by meiotic status and the cumulus oophorus. Molecular Reproduction and Development 62 113-123.

Edwards LJ, Kind KL, Armstrong DT \& Thompson JG 2004 The effects of recombinant human follicle stimulating hormone $(\mathrm{rFH})$ on embryo development in mice. American Journal of Physiology Endocrinology and Metabolism 288 E845-E851.

Eppig JJ, Schroeder AC \& O'Brien MJ 1992 Developmental capacity of mouse oocytes matured in vitro: effects of gonadotrophic stimulation, follicular origin and oocyte size. Journal of Reproduction and Fertility 95 119-127.

Ertzeid G \& Storeng R 2001 The impact of ovarian stimulation on implantation and fetal development in mice. Human Reproduction $16221-225$.

Fagbohun CF \& Downs SM 1992 Requirement for glucose in ligand stimulated meiotic maturation of cumulus cell enclosed mouse oocytes. Journal of Reproduction and Fertility 96 681-697.

Fatehi A, Zeinstra E, Kooij R, Colenbrander B \& Bevers M 2002 Effect of cumulus cell removal of in vitro matured bovine oocytes prior to in vitro fertilization on subsequent cleavage rate. Theriogenology 57 1347-1355.

Gardner DK \& Leese HJ 1987 Assessment of embryo viability prior to transfer by the noninvasive measurement of glucose uptake. Journal of Experimental Zoology 242 103-105.
Gardner DK \& Leese HJ 1990 Concentrations of nutrients in mouse oviduct fluid and their effects on embryo development and metabolism in vitro. Journal of Reproduction and Fertility 88 361-368.

Gardner DK \& Lane M 2004 Culture of the mammalian preimplantation embryo. In A Laboratory Guide to the Mammalian Embryo, pp 41-61. Eds DK Gardner, M Lane \& AJ Watson. New York: Oxford University Press.

Gardner DK, Lane M, Maybach JM \& Hasler JF 2001 Bovine oocyte maturation in a completely defined medium: replacing serum with recombinant albumin and hyaluronan. Theriogenology 55471.

Gardner DK, Reed L, Linck D, Sheehan C \& Lane M 2005 Quality control in human IVF. Seminars in Reproductive Medicine [in press].

Krisher RL 2004 The effect of oocyte quality on development. Journal of Animal Science 82 (E. Suppl.) E14-E23.

Krisher RL \& Bavister BD 1999 Enhanced glycolysis after maturation of bovine oocytes in vitro is associated with increased developmental competence. Molecular Reproduction and Development 53 19-26.

Lane M \& Gardner DK 1996 Selection of viable mouse blastocysts prior to transfer using a metabolic criterion. Human Reproduction 11 1975-1978.

Lane M \& Gardner DK 2004 Preparation of gametes, in vitro maturation, in vitro fertilization, and embryo recovery and transfer. In $A$ Laboratory Guide to the Mammalian Embryo, pp 24-40. Eds DK Gardner, M Lane \& AJ Watson. New York: Oxford University Press.

Leese HJ \& Barton AM 1984 Pyruvate and glucose uptake by mouse ova and preimplantation embryos. Journal of Reproduction and Fertility 72 9-13.

Leese HJ \& Barton AM 1985 Production of pyruvate by isolated mouse cumulus cells. Journal of Experimental Zoology 234 $231-236$.

Merriman JA, Whittingham DG \& Carroll J 1998 The effect of follicle stimulating hormone and epidermal growth factor on the developmental capacity of in vitro matured mouse oocytes. Human Reproduction 13 690-695.

Pincus G \& Enzmann EV 1935 The comparative behavior of mammalian eggs in vivo and in vitro I. The activation of ovarian eggs. Journal of Experimental Medicine 62 665-675.

Roberts R, Stark J, latropoulou A, Becker DL, Franks S \& Hardy K 2004 Energy substrate metabolism of mouse cumulus oocyte complexes: Response to follicle stimulating hormone is mediated by the phosphatidylinositol 3-kinase pathway and is associated with oocyte maturation. Biology of Reproduction 71 199-209.

Roberts R, latropoulou A, Ciantar D, Stark J, Becker DL, Franks S \& Hardy K 2005 Follicle stimulating hormone affects metaphase I chromosome alignment and increases aneuploidy in mouse oocytes matured in vitro. Biology of Reproduction 72 107-118.

Salustri A, Yanagishita M \& Hascall VC 1989 Synthesis and accumulation of hyaluronic acid and proteoglycans in the mouse cumulus cell oocyte complex during follicle stimulating hormone induced mucification. Journal of Biological Chemistry 264 13840-13847.

Schroeder AC \& Eppig J 1984 The developmental capacity of mouse oocytes that matured spontaneously in vitro is normal. Developmental Biology $102493-497$.

Schroeder AC, Downs SM \& Eppig JJ 1988 Factors affecting the developmental capacity of mouse oocytes undergoing maturation in vitro. Annals of the New York Academy of Sciences 541 197-204.

Spindler RE, Pukazhenthi BS \& Wildt DE 2000 Oocyte metabolism predicts the development of cat embryos to blastocyst in vitro. Molecular Reproduction and Development 56 163-171.

Sutton ML, Cetica PD, Beconi MT, Kind KL, Gilchrist RB \& Thompson JG 2003 Influence of oocyte-secreted factors and culture duration on the metabolic activity of bovine cumulus cell complexes. Reproduction 126 27-34. 
Sutton-McDowall ML, Gilchrist RB \& Thompson JG 2004 Cumulus expansion and glucose utilisation by bovine cumulus-oocyte complexes during in vitro maturation: the influence of glucosamine and follicle stimulating hormone. Reproduction 128 313-319.

Van de Leemput EE, Vos PL, Zeinstra EC, Bevers MM, van der Weijden GC \& Dieleman SJ 1999 Improved in vitro embryo development using in vivo matured oocytes from heifers superovulated with a controlled preovulatory LH surge. Theriogenology 52 335-349.

Van der Auwera I \& D'Hooghe T 2001 Superovualtion of female mice delays embryonic and fetal development. Human Reproduction 10 1237-1243.

Zhang I, Jiang J, Wozniak P, Yang X \& Godke R 1995 Cumulus cell function during bovine oocyte maturation, fertilization, and embryo development in vitro. Molecular Reproduction and Development 40 338-344.

Zuelke K \& Brackett B 1992 Effects of lutenizing hormone on glucose metabolism in cumulus enclosed bovine oocytes matured in vitro. Endocrinology 131 2690-2696.

Received 1 June 2005

First decision 7 June 2005

Revised manuscript received 23 June 2005

Accepted 27 June 2005 